\title{
Loxocelismo cutáneo
}

\author{
Skin Loxocelism
}

Dyanne N. De la Rosa ${ }^{1,2, a}$, Mayron D. Nakandakari ${ }^{1,2, a}$, Walter Bryson ${ }^{3, b}$, José Arias ${ }^{4, c}$

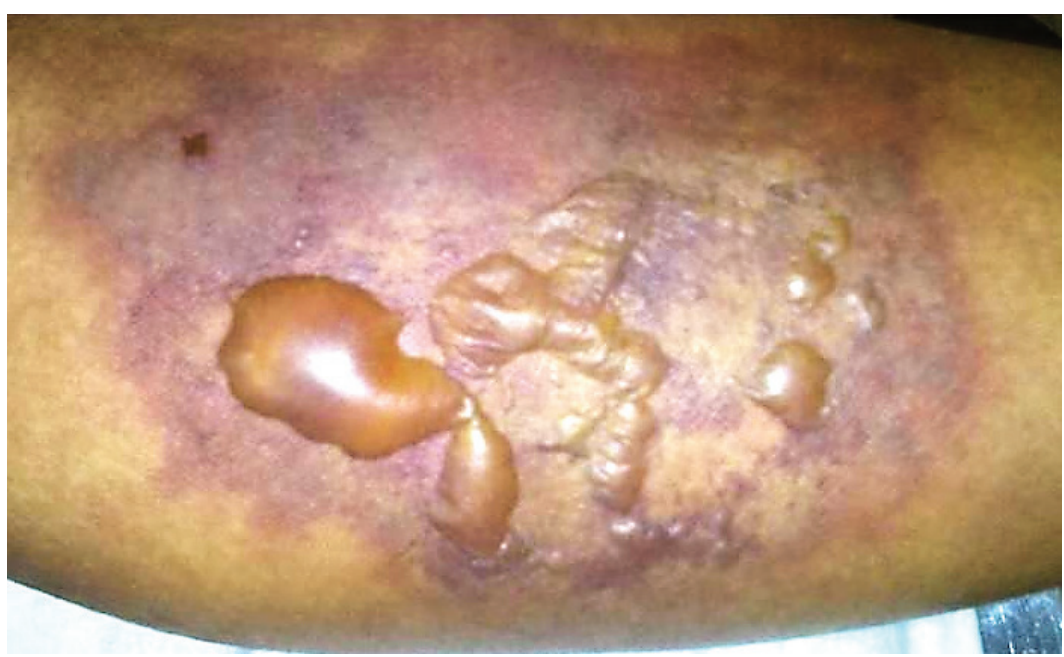

Varón de 23 años, VIH positivo, quien sufrió de mordedura de araña mientras limpiaba su sótano. La araña fue identificada como Loxoceles laeta. Presentaba una lesión localizada en los dos tercios distales del miembro superior izquierdo, observándose una placa violácea, necrótica, de unos 9,5 $\mathrm{cm}$ de alto y de 6,8 cm de ancho, de bordes mal definidos, dolorosa y con flictenas. Se le realizó curaciones con apósitos y tratamiento oral con antihistamínicos, antibióticos y antiinflamatorios. Luego de aproximadamente un mes de ocurrida la mordedura, las lesiones habían desaparecido y el paciente se encontraba asintomático.

23 year old male, positive HIV, who suffered spider bite while he cleaning his vault. The spider was identified as Loxoceles laeta. He had a lesion located in the distal two thirds of the left upper limb, showing a purple, necrotic plate, about $9.5 \mathrm{~cm}$ high and $6.8 \mathrm{~cm}$ wide, poorly defined, painful blisters and edges. He underwent treatments with dressings and treatment with oral antihistamines, antibiotics and anti-inflammatories. After about a month of the bite occurred, the lesions had disappeared and the patient was asymptomatic.

\section{Correspondencia:}

Dyanne Nellybeth De la Rosa Campos

Mz. F Lot. 8 Chacra Cerro - Comas. Lima, Perú.

Teléfono (51) 1 557-2275 / (51) 986-158316

Correo electrónico: delarosa.dyanne27@gmail.com

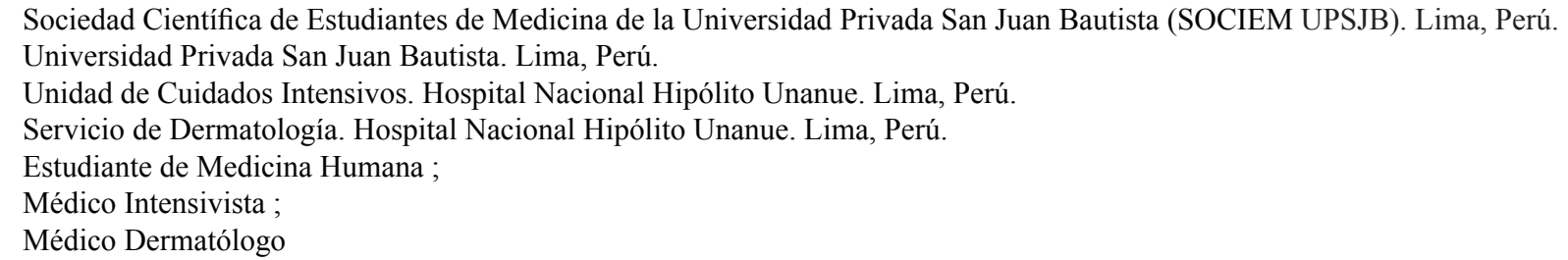

